\title{
ATTRACTING SKILLED MIGRATION TO THE CZECH REPUBLIC - LAGGING BEHIND? ${ }^{1}$
}

\author{
Hana N. Hlaváčková2, Lucie Macková ${ }^{3}$
}

\begin{abstract}
This paper attempts to explore the issue of skilled migration and the approach of the Czech Republic when it comes to attracting and retaining foreign skilled workers. The global competition for talent has been a prominent issue in migration studies, mainly because it has been shown that qualified migration can have a positive impact both on the countries of origin and of destination. The Czech Republic, with its low levels of unemployment, might benefit from the human capital offered by the skilled migration, and yet, there is surprisingly little debate about the type of migration the Czech Republic wants to attract. At best, this debate is driven by short-term employer demands. Surprisingly, there is little research about skilled migration to the Czech Republic and other CEE states despite its clear benefits. This paper will explore the Czech policies and programmes dealing with skilled migration and the possible caveats of these programmes. The main aim of this contribution, done by qualitative and quantitative content analysis, is to analyze past and ongoing programmes of migration and integration policy of the Czech Republic regarding skilled migration. Furthermore, it attempts to shed light on the discursive, implementation, and efficacy gaps in the Czech policies.
\end{abstract}

KEY WORDS: Skilled migration, Migration policy, Czech Republic, Effectiveness, Efficacy, Policy gaps, Implementation

\section{INTRODUCTION}

Migration policies come to political and scholarly interest with the process of the interdependency of states and later with globalization and changes in the international system. Migration is driven by various structural factors as well as individual motivations and aspirations. In the field of international

\footnotetext{
${ }^{1}$ This paper is the result of Metropolitan University Prague research project no. 74-02 "Territorial Studies, Economics, International Relations" (2020) based on a grant from the Institutional Fund for the Long-term Strategic Development of Research Organizations.

${ }^{2}$ Department of International Relations and European Studies, Metropolitan University Prague, Dubečská 900/10, Praha, Czech Republic, E-mail: hana.hlavackova@mup.cz.

Czech Republic

${ }^{3}$ Faculty of Science, Palacký University Olomouc, 17. listopadu 12, Olomouc, Czech Republic, E-mail: lucie.mackova@upol.cz.
} 
relations scholars focus on migration flows per se, but also research policy effectiveness and ask whether such policies regulating migration are successful. The trends are easily tracked - migrants from less developed countries seek work in developed countries but in fact, most migration worldwide takes place within the developing countries (IOM, 2017). From the perspective of the EU, the EU labour market needs workers from the third country. At the same time, states are determined to select those they let in and therefore, create migration policies. This text will discuss the policy of a particular state which attempt to attract skilled workers from abroad. Moreover, it will discuss the practicalities of these policies on the ground, i.e. what happens to the workers once they arrive in the Czech Republic.

Currently, the Czech labour market is missing several hundred thousand workers, including in the skilled professions (Ihned.cz, 2018). Therefore, attracting high-quality workers is of utmost importance for the Czech labour market, for companies and for ensuring the competitiveness of the Czech Republic. Currently, there is also a mismatch between the education of immigrants and the professions they work in (Koutná - Krčková - Vavřinová, 2016; Valenta - Drbohlav, 2018), which can suggest that there are certain obstacles for many of them. However, the situation for the migrants who come through the programmes for skilled migrants is not better. In general, we can distinguish between the state policies relating to skilled employment: 1) policies which attempt to retain the country's skilled workers, 2) policies attempting to attract skilled workers from abroad, and 3) policies which attempt to use the skills of highly qualified workers who are residing abroad (Kostelecká - Bernard - Kostelecký, 2007).

The case of the Czech Republic was selected because the region is relatively under-researched when it comes to skilled migration and adds to the diversity of migration policies across Europe. As has been argued by King and Okólski (2019), the shrinking economic differences between eastern and western countries of the EU and changing demographic dynamics will soon add to the diverse migration patterns in the CEE regions. These changes should be reflected in the migration policies. As Burkert, Niebuhr, and Wapler (2007) assert, regions with similar characteristics usually compete for skilled workers (London versus Frankfurt, not Britain versus Germany). Therefore, the Czech programmes will likely compete with similar ones in the region. The Czech Republic is not likely to compete with the USA, Canada, or Australia, who are the leaders in attracting skilled migrants. However, it can compete with its neighbours and thus, it is important to understand the implications of the Czech migration policies. 
Scholars seek a definition of migration policy due to the huge number of actors and their interests that participate in the process of setting up the migration policy. We have chosen particular actors to make clear evidence of who is a creator of migration policy and to show the weaknesses of the current system. According to Burkert, Niebuhr, and Wapler (2008) migration policies should provide a general framework for competition for talents at the national level. What we can observe in practice in the Czech case is that often the red tape prevents using most of the benefits of the migration policy itself. This is due to the setting of the migration policy, which might influence both the qualitative and quantitative structure of skilled migration coming to the Czech Republic. However, there may be other factors at play. This paper attempts to answer the following research questions: What gaps appear during the implementation of the Czech migration policies regarding skilled migration? Why did those gaps appear? With this topic, we would like to add to the discussion about the effectiveness of migration policies that was started by Czaika and de Haas (2011) and on this example show that one of the gaps - the implementation gap - shows only one part of the puzzle but there is a need to add the realist optics, the cost vs. benefit point of view because the government creates a policy that is wanted by the society due to the reasons of the effect of reelection. So the effectiveness of some policies matters but others do not. We will ask whether the migration policy is the one that does not matter in the Czech view.

This paper attempts to track the major policy changes concerning skilled migration in the Czech Republic. First, we introduce the benefits of skilled migration and why the global competition for talent is needed to be competitive in the global labour market. We also introduce the three policy gaps - the discursive gap, the implementation gap, and the efficacy gap. Second, we introduce the methods for this paper and how we analyzed the gaps. Third, we look into the evolution of the Czech migration policies and the ways how they reflected (or did not) skilled migration and the specific programmes aiming at skilled migration. In this section, we also discuss the main actors of the Czech migration policy. Then we discuss the policy gaps regarding skilled migration in practice and finally, we conclude by the possibilities to close those gaps.

\section{THEORETICAL FRAMEWORK}

Skilled migration has attracted the attention of both scholars and policymakers. Two perspectives are prevalent in the literature. The first perspective 
argues that skilled migration is seen as a way of developing the economies of the countries of origin through remittances, trade, foreign direct investment, or social remittances. It draws on the idea that skilled migration contributes to human capital and international development. We can note the example of Silicon Valley in the US which draws on the economic contributions of Asian migrants. For instance, in 1998, Chinese and Indian engineers were senior executives at one-quarter of Silicon Valley's technological businesses (Saxenian, 2002). The issue of human capital is especially important for skilled migrants themselves and the receiving countries. For example, Lucas (2005) argued that the accumulation of human capital can take place through schooling and in the process of on-the-job training when the level of skills increases. Moreover, knowledge transfer can occur through informal training, learning by example, and sharing new ideas (Kuschminder et al., 2014).

However, there is also the second perspective which takes into account the issue of brain drain, or the departure of skilled professionals, which can have profound effects on the local economies, especially in countries with high levels of emigration. While the issue of brain drain was first explored in the literature in the 1970s (Bhagwati, 1976), the issue later turned to brain gain (Lucas, 2005) or brain circulation (Docquier - Rapoport, 2011; Saxenian, 2006) which are perceived as beneficial for the migrants, the countries of origin and the receiving states. Some scholars found that migration contributes to raising the living standards for those left behind and increases human capital (Adams, 2006; Adams - Page, 2005). However, others describe these situations as 'deskilling' or 'brain waste' (Nowicka, 2012). This happens when migrants find occupations that are below their skill levels - a clear example of which is someone who is a doctor by training but works as a taxi driver. Gibson and McKenzie (2012) found that the migration of highly skilled individuals has substantial benefits but mainly for the migrants themselves who gain greater income. Moreover, they found that most high-skilled migrants remit but their involvement in the trade or foreign direct investment is rare. Sturge, Bilgili, and Siegel (2016) argue that highly skilled migrants to the Netherlands are in a better position to contribute to the development in their countries of origin, by the way of economic and social remittances. Therefore, skilled migration is generally seen as beneficial to both the migrants and the receiving countries.

When discussing professional migration, there is a need to be more specific about the definition, because there are a few groups that can differ. There is no single definition of skilled migration or international talent. 
Presently, there seems to be a trend of defining skilled migration in terms of occupations (e.g. managers, healthcare workers, scientists) and moving away from educational qualifications (Kuvik, 2012). This is because the policies of EU countries focus mainly on labour market demands. For example, Solimano (2008, p. 4) defines three main types of skilled migrants - directly productive talent, academic talent, and talent in social and cultural sectors. However, highly skilled jobs can also be delineated concerning the salary level. The Blue Card Directive defines it as providing at least 1.5 times the average gross annual salary in the EU country concerned (Council of the European Union, 2009).

Current migration studies focus on observing migration from different standpoints at the global, regional, subregional, state, substate, and individual levels of analysis. Brettell and Hollifield (2015) stress that international relations scholars put the state into the center of study, which is not wrong but scholars should not forget about the meso level that focuses on social ties. We will focus on the state level where the migration policy is created on other levels (meso level included) because our aim is not only to show how the migration policy looks like but also to explain why it looks the way it does. We would like to stress the context of migration policy towards skilled migrants and continue in the academic debate about how the migration policies can be studied.

Usually, when someone observes a policy issue, scholars ask about the migration effect, what the problem or solution is, what the explanations are, or how something influences other things. Those questions are usually stated within strictly empirical research and this is appropriate. However, when scholars want to contribute to the academic debate, there is a need to put the problem in a broader context. To measure the effectiveness scholars use more often quantitative methods but qualitative methods are as valid as the quantitative ones (Czaika - de Haas, 2013, p. 505). In the perspective of effectiveness, scholars focus on the failures of migration policies. With the detection of failures Czaika and de Haas claim that we should be aware of not mixing failures of policies with no effect changes in policy patterns. It is also necessary to distinguish between changes in policy regimes (major systemic changes and their effects) and minor policy changes within the existing regime. One problem with researching migration policies is the measurement of their effects. According to Czaika and de Haas (2013, p. 487), migration policies have only a limited effect on the long-term volume and trends of migration. Others (e.g. Brochmann - Hammar, 1999) claim that migration policies can have effects when states implement beneficial policies. 
However, migration cannot be measured only by the migration policy itself because the migration flows are also influenced by the economic level of the country, state of education, healthcare system. Researchers have to decide what is the intended effect of the policy and its real objectives. There are two ways how to track migration policy - discourses around it or the facts - objectives, outcomes, and gaps, or both (Czaika - de Haas, 2013). Czaika and de Haas (2013) claim that it is possible to observe migration policy effectiveness when researchers distinguish dimensions and levels of aggregation at which researchers assess migration policy outcomes. We distinguish an exact dimension, because of our focus on skilled migration, and the level of aggregation is the state level. From this standpoint it is possible to observe a gap between policy rhetoric and the actual policy objectives. This is what de Haas and Czaika (2011) call discursive gap vs. implementation gap. In 2013, they added a third possible gap, which is the efficacy gap. Gaps are an objective of current studies according to Hollifield (2000; see also Cornelius - Martin - Hollifield, 1994) who claim that the gaps hypothesis can be useful due to determining the main problems that slow migration policy effectiveness.

The following three gaps are analyzed in this paper - the discursive gap, the implementation gap, and the efficacy gap. The discursive gap shows the differences between discourses and migration policy on paper in the form of laws, regulations, and measures. According to Fairclough (1995), discourse means interviews, statements, or pictures that are connected to the topic. We work with this definition to analyze discourse. To observe a discursive gap does not mean that the policy is failing (Czaika - de Haas, 2013, p. 494). Actors in the observed discursive gap are not only politicians but also interests groups or different institutions. The implementation gap refers to the policy on paper and its actual implementation. We did not focus on interviews, which would have been useful, but we studied migration policies concerning skilled migration so we can conclude with a few observations. Implementation can show possible real failures. However, it is impossible to measure the degree to which policies on paper are implemented. The efficacy gap appears when the implementation of the policy does not affect the volume, timing, direction, and composition of migration flows, in our case of skilled migration. On one hand, with the study of the efficacy gap, we can observe policy failures. On the other hand, migration (including skilled migration) can be driven by structural factors in the country of origin and destination country. Therefore, all three gaps are important for our understanding of the policies regarding skilled migration. 


\section{METHODS}

We use interpretive critical content analysis to answer the research questions. The main sources we analyzed were the legal documents concerning skilled migration in the Czech Republic, which are available on the websites of different ministries responsible for these programmes. The timeline for this study is from 2003 (when the first project on skilled migration took place) until September 2019, with an emphasis on the contemporary period (with the observed discourse gap we set period 2015-2019). We especially look at policy effectiveness according to the above mentioned theoretical framework and the gaps in the migration policy created by the Ministry of Interior as a main and major actor proposing laws and strategies in this field. Then we focus on the Ministry of Labour and Social Affairs who deal with particular activities concerning migration at all, and last but not least Ministry of Industry and Trade who also participates in the process of attracting skilled workers, especially cooperation with employers who are interested in employing foreign workers. These ministries together and their special departments are part of the process of creating the laws and are the bodies who deal with the policy in praxes. Of course, there are other actors such as NGOs but we will not focus on them due to we are interested in the policy itself. We also inquire about the reality of the programmes on the ground and propose how to overcome the gaps.

Czaika and de Haas (2011) discuss immigration policy effectiveness which is an object of study that is not easily observed. One problem is with showing causality in causal interpretative research, which should prove that a change in migration flows is a result of a policy change. The problem is that we can hardly state to what extent such changes are influenced by a policy change. The effects mean the casual ability of policies to affect migration flows and the effectiveness shows the relation to policy objectives and empirical assessment. The effects are mostly measured by quantitative studies but those are not able to measure the degree of effectiveness of such a policy. In our causal research, we observe dependent (result - current state of migration policy regarding skilled workers) and introduce independent variables (known inputs which influence the inception of policies and following causes that affect the result - current state of migration policy regarding skilled workers). We would also like to observe intermediary variables, which influence the dependent variables. These are other factors, which also influence the resulting policies. We have only one case (the Czech Republic) so those variables help us more to organize the qualitative 
research. In table 1 below we set independent variables that influence the policy effectiveness and possible intermediary variables that will be observed if they matter in the Czech case. The research of variables will be done in documents concerning migration as a secondary literature and primary sources such as documents from the Ministry. Those variables are inputs that affect the outcome. Our goal is to follow them while observing documents and webpages and realize if they matter and if the ministries take them into account or not while activating programmes in migration policy towards skilled workers.

Table 1: Independent and intermediary variables that influence the policy effectiveness

\begin{tabular}{|c|c|}
\hline Independent variables & Intermediary variables \\
\hline missing workers on a labour market & interests of particular politicians \\
\hline $\begin{array}{l}\text { not unified migration policies within the } \\
\text { EU }\end{array}$ & interests of particular ministries \\
\hline $\begin{array}{l}\text { CR as a competitor for skilled migrants in } \\
\text { the region }\end{array}$ & $\begin{array}{c}\text { interests of other actors who can parti- } \\
\text { cipate in the process of admitting skilled } \\
\text { workers }\end{array}$ \\
\hline $\begin{array}{l}\text { lack of EU law commitments that can } \\
\text { change Czech policy }\end{array}$ & \\
\hline $\begin{array}{l}\text { national economic crises over time that led } \\
\text { to more restrictive migration policies }\end{array}$ & \\
\hline the brain drain of $\mathrm{CR}$ & \\
\hline $\begin{array}{l}\text { former projects towards skilled migrants } \\
\text { that were not effective (blue card, green } \\
\text { card) }\end{array}$ & \\
\hline state of European labour market & \\
\hline
\end{tabular}

Categorical substitution effects are one of the reasons that limit the effectiveness of migration policy. They can be, for example, the shifts of migration flows from labour to family (de Haas - Czaika, 2011). While discussing the shifts, the skilled migration should be one of the main objectives of the migration policy to attract "the best and brightest" and to develop states' economies. From the long term perspective, it goes hand in hand with family reunification and integration of the whole family into the mainstream society. This process of integration should be the easiest for the skilled workers. The effects and effectiveness of migration policy can 
decrease to serve different policy goals. For example, selective migration policy may make family reunification more difficult.

We have inquired about the following three gaps by different means and the results are presented in the section on the gaps of the Czech skilled migration policy. The discursive gap was observed in the political statements of the Ministry of the Interior and the policy laws and formulations and other two ministries participating in migration regarding skilled workers. We have observed webpages and official statements and add also quantitative content analysis to stress the main difficulties in migration policy. The discursive gap was also studied by a quantitative method and the results are interpreted below. The implementation gap was observed by inquiring about migration policy regarding skilled migration and its regulations and measures. We focused on the difference between means and goals, mainly discretion, resources, (hidden) interests, and constraints. The efficacy gap, as explained above, was observed by migration outcomes that we have studied mainly from secondary literature due to the lack of sources regarding skilled workers and studied period. The focus on skilled migration in this gap is in to observing the change of volume, composition, timing, and direction of migrants.

\section{THE EVOLUTION OF THE CZECH MIGRATION POLICIES AND SKILLED WORKERS PROGRAMMES}

First, we will briefly introduce the general migration policies in the Czech Republic and then we will look specifically into the policies relating to skilled migration. Some authors have discussed the general Czech migration policies in different periods (Baršová - Barša, 2005; Kušniráková - Čižinský, 2011; Bauerová, 2018). Baršová and Barša (2005) propose several migration policy periods in recent history - from the liberal or laissez-faire since the 1990s towards more restrictive in the second half of the 1990s, during which the Law on the Residence of Aliens in the Territory of the Czech Republic was passed. The following period could be characterized by the convergence of the Czech and EU law which continues up to now. Kušniráková - Čižinský (2011) discuss the dependency of Czech migration policies and Bauerová (2018) inquires about the changes in migration policy towards migrants and their integration in the Czech Republic.

We can observe the linkages between the economic cycles and migration policies, for example, the national economic crisis in 1997-1998 coincided with the more restrictive period of the Czech immigration policy (Bauerová, 
2018). Similarly, the economic downturn after 2008 led to the restrictions in the numbers of immigrants. The Czech Republic has one of the lowest unemployment rates in the EU and therefore, skilled migration is needed, not least because the Czech Republic has experienced brain drain, especially in areas such as healthcare, research, or technical professions. While the situation with the outgoing labour force is not as severe as in Poland or Slovakia, it nevertheless requires further attention.

The main changes in the Czech policies are influenced by EU legislation. At the beginning of the new millennium, there were few EU-wide programmes to attract skilled migrants. Research in this period focused mainly on international companies, expatriates, or managers (e.g. Koser - Salt, 1997). New programmes for highly-skilled immigration in Europe have been introduced since the mid-2000s, with the UK being the first EU country to have adopted the first large scale skilled migration programme in 2002 (Kuvik, 2012). The first pilot programme aimed at skilled migration to the Czech Republic took place from 2003 to 2010, which first addressed potential immigrants from three countries (Croatia, Bulgaria, and Kazakhstan) and was later extended to other countries. This project was titled "Selection of Qualified Foreign Workers" and was launched by the Ministry of Labour and Social Affairs. However, the project had strict conditions and its end coincided with the shrinking of available workplaces (Valenta, 2013). In total, there were less than 2000 workers taking part in this programme and less than 2000 of their family members, mainly from Russia, Bulgaria, or Belarus (MPSV, 2010). On one hand, the workers could apply for a permanent residence in a shorter time (three years). On the other hand, the state did not assist them with the visa or with finding employment (Bauerová, 2018).

The next project was the introduction of the Green cards and Blue cards in 2009. The Green cards, which are no longer in use, aimed at the demand for workers by companies and was used as a residence and work permit at the same time. The project was initiated by the Ministry of Industry and Trade (Bauerová, 2018). There were three types of green cards, one of which aimed at skilled workers (Valenta, 2013). However, the problem with this document was that it did not allow the workers to change their employers. The Green cards were not hailed as a success, mainly due to the low number of users. The explanation for that could be due to the economic turndown during this period or due to the legislative and administrative barriers connected to this measure (Valenta, 2013). One example of these would be the difficulties with the recognition of foreign qualifications. The Green card project was discontinued in 2014 and since then it has been replaced by 
the so-called Employee card. However, we can note that it was a national initiative that started at the same time as the EU Blue card programme.

The Blue card programme, based on an EU-wide scheme, allows the workers to change their employment which is beneficial for the workers themselves but also the general labour conditions in the Czech Republic. The scheme aims at skilled workers who have completed at least tertiary education of three years (MPSV, 2018). Both cards allow the workers to stay for the duration of the work contract which can be repeatedly extended by no more than 2 years. The difference between the Blue card and the Employee card is in the levels of education (the Employee card is for all skill levels). There are also other specific programmes aiming at skilled workers who are currently starting. The new governmental programs with effect from 1 September 2019 are Programme Key and Research Staff (replacing Project Fast Track and Project Welcome Package), Programme Highly Qualified Workers (replacing Pilot Project Ukraine and India) and Programme Qualified Workers (replacing Project Other States and Project Ukraine) (MPO, 2019a).

While the EU-wide Blue Card programmes are meant to be transferable across the EU (except Denmark and Ireland), there are still differences in the countries involved and the conditions they have on the Blue Card holders (e.g. the salary level or the maximum period for granting this document - 2 years in the Czech Republic vs. 4 years in Germany). Germany is the biggest provider of Blue Cards, with $85 \%$ of the total number of cards provided since 2012 going there. It is followed by France, Luxembourg, Poland, and Italy (BAMF, 2018). In the Czech Republic, the person has to report to the Ministry of the Interior within three working days that they have lost their job. After two years of stay in the Czech Republic, the person has to report any changes via an online form which is only available in the Czech language (MPSV, 2019).

The job offers for the Blue Card holders are mainly in the fields of IT, engineering, or medicine. This seems to be similar across all EU states. Each state prepares its programme according to what class of employment is needed most. In the Czech Republic, there are 9 (main) classes of employment classification: 1) high management; 2) researchers; 3) technical, medical, pedagogical and other workers from familiar fields; 4) lower administrative workers; 5) service workers; 6) qualified workers in agriculture and forestry; 7) craftsmen, qualified manufacturers and repairmen; 8) machine and equipment operators; 9) unqualified labourers. It is possible to observe that there are 8 classes of so-called qualified migration workers. In the Czech 
Republic, the Ministry of Labour and Social Affairs (MPSV) has created 3 major groups to deal with the migration policies concerning labour migration and qualified workers: 1) skilled workers including 1-3 above-mentioned classes; 2) semi-skilled workers from classes 4-8 and 3) unskilled workers from class 9. In this text, we deal with the concept of skilled (or qualified) migration which is rooted in the programmes of ministries and includes high management, researchers and technical, medical, pedagogical, and other workers (often IT specialists). We work with this classification because the policy we observe is focused on the first three categories.

Table 2: Employment categories in the Czech Republic

\begin{tabular}{|c|r|c|}
\hline $\begin{array}{c}\text { Employment } \\
\text { category }\end{array}$ & Class of employment classification & \multirow{2}{*}{ Skill level } \\
\hline 1 & high management & \multirow{2}{*}{ Skilled } \\
\hline 2 & Researchers & \multirow{2}{*}{ semi-skilled } \\
\hline 3 & technical, medical, pedagogical workers & \\
\hline 4 & lower administrative workers & \multirow{2}{*}{ service workers } \\
\hline 6 & qualified agricultural and forestry workers & \\
\hline 7 & craftsmen, qualified manufacturers and repair- & \multirow{2}{*}{ Unskilled } \\
\hline 8 & machine and equipment operators &
\end{tabular}

Source: authors according to CZ-ISCO (2019)

\section{THE KAFKAESQUE REALITY OF THE PROGRAMMES}

At the end of April 2019, there were 209828 job candidates and 339919 free working places in the Czech Republic (MPO, 2019b). Those numbers show that the Czech job market needs to be strengthened by foreign workers not to slow down the Czech economic growth this year. The easiest way to do that is by employing foreigners from the EU who do not need any special permits. However, there is fierce competition for them among all the EU member states. Therefore, the Czech Republic needs to rely on skilled workers from the so-called third countries. Concerning the abovementioned programmes, there is a huge number of actors who participate in them and who might even stand in the way of a skilled worker coming to the Czech Republic to work, share know-how and knowledge. The Czech 
migration policies are influenced by the declared interests of the Czech ministries (mainly the Ministry of the Interior, the Ministry of Industry and Trade, and the Ministry of Labour and Social Affairs) and their implicit interests regarding the economy and national security. Last but not least, the activities of civil society can also be influential (Drbohlav, 2010). Therefore, there are various actors with different interests who are important for Czech migration policies.

The first major actor is the Ministry of the Interior which supervises migration policy and sets the conditions under which foreigners can come and stay in the Czech Republic. A skilled person from a different country can find a job position at the website of the Ministry of Labour and Social Affairs. But sometimes a specific employer seeks a specific employee from partner countries and for such a situation the Ministry has devised its programmes. There are a few steps before the position goes public and the employer finds their proper employee. An employer who would like to hire a skilled worker from abroad (project countries are easier to reach) has to apply in advance. Interestingly, the employer needs to decide whether it is better to apply for one or more than fifty workers because the Ministry has the application form for only one worker and then more than fifty. If an employer would like to hire more than one worker, they need to repeat the process.

The above-mentioned programmes show an easier way for employers to get their skilled workers "faster". The first step is to report to the Labor office that there is a working place that has not been possible to fill by a Czech worker for more than 30 days. In this case, such working place can be filled by a foreign worker with the Employee card. Then the Labor office agrees that this place can be filled by a skilled migrant. In the next step, the employer applies to the programme guarantor. There are a few reasonable conditions to decide whether this employer can be accepted or not. It needs to be the payer of VAT, have no unfulfilled obligations towards state, and at least one year of experience. The guarantor of the government programme is, for example, CzechInvest and others. When the guarantor decides that this employer fulfills the criteria, it immediately informs the Ministries who deal with the special program (Ministry of Labour and Social Affairs, Ministry of Industry and Trade, Ministry of Interior, Ministry of Foreign Affairs) and the contact of the specific skilled person is sent. In this context, we need to stress that the employer and potential employee need to be in contact before the whole process even starts.

Afterward, the Ministry of Foreign Affairs contacts the Consulate General in Lviv (in case of the programme in Ukraine). The Consulate General contacts 
an external agency that contacts the potential worker and sets a date when they meet. All paperwork needs to be ready, otherwise, the date will be canceled. If the worker cannot come at the date set by the external agency, the date is canceled and the worker is discarded from the programme. The potential worker asks for the Employee card from this external agency. When the paperwork is done, the external agency informs the Consulate General who informs the Ministry of the Interior's OAMP - the Department of Asylum and Migration Policy.

OAMP decides whether the potential employee gets the Employee card. If yes, then again Consulate-General is asked to cooperate and give a long term visa for purposes of the takeover of the Employee card. The potential worker can now enter the Czech Republic and has to visit OAMP in no longer than three days and give his or her biometric data. At OAMP the potential employee receives confirmation of fulfillment of conditions for the Employee card. Then, they can start to work. This is not the end of the process for the employer or employee. The employer has to cooperate with the Centre for the Integration of Foreigners. However, it is not specified how. If the employer applies for more than fifty persons, they also need a letter of interest from the mayor of the city where the workers will be accommodated. The workers have to attend an integration course.

The usual schedule is:

1. inclusion of the employer in the project takes 5 days - the responsibility of the Ministry of Industry and Trade and Ministry of International Affairs

2. addressing the candidate in the country of origin and granting a meeting date - 14 days (there is no obligation for an external agency) - the responsibility of Consulate General

3. interview date - within 7 working days - Consulate General

4. employee card issuance proceedings - from 60 to 90 days

This schedule does not include the period when an employer asks for permission from the guarantor and the period when the guarantor informs all ministries. Such conditions do not create a friendly environment for skilled workers who would like to work in CR. Those conditions pretend to be easier than regular foreign workers with the whole process. With this project there has to be a clear connection between employer and worker before the process of asking for permission even to start. We can also observe, that the Ministry of Foreign Affairs has its deal in the process. This ministry tasks the Consulate General abroad, so it could influence the 
number of skilled workers. Also with its programmes of public diplomacy could the Ministry of Foreign Affairs affect skilled migration. However, after searching for such activity on the website of Ministry, we can conclude, that there could be activity inside Eastern partnership bilateral meetings, but there was no mention of any structured activity towards skilled workers or any organization that could mediate cooperation.

\section{GAPS OF THE CZECH SKILLED MIGRATION POLICY}

In this section, we attempt to observe the above-mentioned gaps according to Czaika and de Haas (2011) in the case of the Czech migration policy concerning skilled workers. The discursive, implementation, and efficacy gaps can explain migration policy failures, weaknesses, and shortcuts (or "longcuts") that are arising from the policy itself. However, one needs to pay close attention to what exactly the failure of policy is and what is not. We have stated that migration policy regarding skilled workers has several constraints and below are those problems through the optic of theory.

First of those three gaps is the discursive gap, which is not as big as expected. We supposed that skilled workers generally seen as an advantage for the Czech economy would be a topic of high priority. However, brief research of discourse shows that this hypothesis was wrong. Only a few mentions about skilled migrants as the priority were shared by the Minister of the Interior when introducing a new law. Having searched through other sources, there was no visibility of importance placed on this topic. This situation is supported by the number of mentions of webpages of ministries. The Ministry of the Interior is responsible for the whole migration policy, so this ministry should at least mention such policy or efforts of its implementation, but the reality is opposite from the expectations. Neither the Ministry of the Interior, nor the Ministry of Industry and Trade, two administrative bodies that are responsible for and have their interest in getting skilled workers, mention it as a priority.

Since the 1st September 2019, "Government Resolution No. 581 of August 26, 2019 on Programs Approved by the Government for Economic Benefit for the Czech Republic" has been in place (Government of the Czech Republic, 2019). This resolution mentions that highly skilled workers are economically beneficial for the Czech Republic. We could say that the discourse about the skilled workers is middling and the practice corresponds to that discourse. Migration policy regarding skilled workers is not the top priority as could be 
observed in the documents. When the government deals with migration, it is mostly seen through the security optic and the economic benefits are rarely mentioned. We can demonstrate it below on the quantitative exploration of the topic.

Firstly we have observed the Ministry of Interior. From 141 statements in 2019, when major changes in the policy of attracting skilled migration have been processed in the Parliament and Senate, only 10 of them concerned migration. None of them have mentioned skilled migration. The statements consist of migration as a threat on the border of the EU (mainly in the Western Balkans) and need to help the countries at the external EU border. The Ministry of the Interior mentioned the cooperation with those countries a few times. The Ministry of the Interior is the most salient migration policy actor in the Czech Republic and therefore, we will illustrate its approach towards skilled migration by the following statements. In 2018, 13 statements out of 170 were about migration and only one about skilled migration when the Ministry of the Interior informed about changes in laws concerning skilled workers. The statements illustrate that the Ministry of the Interior informed about migration largely from a security point of view, not mentioning benefits that can be brought from skilled workers. While there are statements about migration, they are usually connected to security measures even when there are mentions about the lives of foreigners in the Czech Republic.

Table 3: Mentions of migration and skilled migration at the Ministry of the Interior website

\begin{tabular}{|c|c|c|c|c|}
\hline ঠँ & 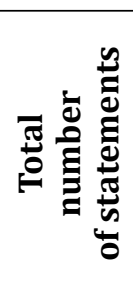 & 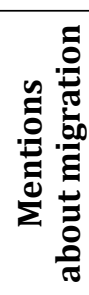 & 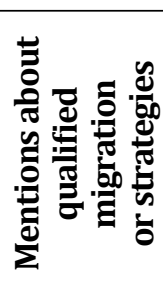 & 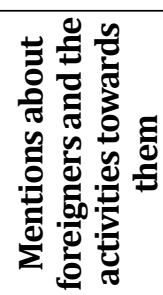 \\
\hline $\begin{array}{l}2019 \text { (up to } \\
\text { October 23) }\end{array}$ & 141 & 10 & 0 & 3 \\
\hline 2018 & 170 & 13 & 1 & 4 \\
\hline 2017 & 154 & 12 & 0 & 4 \\
\hline 2016 & 169 & 8 & 0 & 2 \\
\hline 2015 & 185 & 21 & 0 & 2 \\
\hline
\end{tabular}

Source: authors according to the webpage of MVCRR $(2019,2018,2017,2016,2015)$. 
The ministry publishes quarterly migration reports. To be precise, there are five reports since the year 2018 when the ministry decided to publish such reports. The reports aim to "information about the topics dealing with migration." However, only one report out of five (3rd report in 2018) mentions the topic of skilled migration concerning skilled workers. The other reports connect migration with security or development as the Czech Republic sends money to the Western Balkans countries, among others, to deal with the effects of migration.

Second, we have observed the Ministry of Labour and Social Affairs as other key actors in practical activities dealing with skilled workers. It participated in the key programmes, as we mentioned those programmes were run in this ministry. On its webpage is the same information about conditions on how to employ a worker from a non-EU country. We have followed statements as well as in the Ministry of Interior. Ministry of Labour and Social Affairs is focused more on Czech workers working abroad or in the process to work abroad. On the other hand Ministry of Labour and Social Affairs take care of foreign workers from abroad discussing conditions in dormitories or job conditions and problematic of job agencies.

Table 4: Mentions of migration and skilled migration at the Ministry of Labour and Social Affairs website

\begin{tabular}{|c|c|c|c|c|}
\hline$\overbrace{\beth}^{\bar{\varpi}}$ & 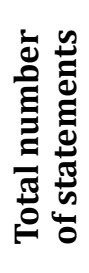 & 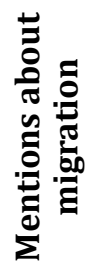 & 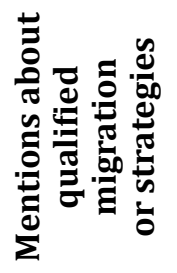 & 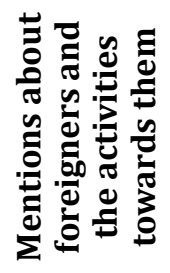 \\
\hline $\begin{array}{l}2019 \text { (up to } \\
\text { October 23) }\end{array}$ & 170 & 2 & 0 & 2 \\
\hline 2018 & 132 & 2 & 0 & 2 \\
\hline 2017 & 320 & 0 & 0 & 0 \\
\hline 2016 & 185 & 2 & 0 & 2 \\
\hline 2015 & 269 & 1 & 0 & 1 \\
\hline
\end{tabular}

Source: authors according to the webpage of MPSV $(2019,2018,2017,2016,2015)$

Most of the statements were about foreign workers, but no high skilled workers. Ministry focuses on the legal basis of their work, keeping the rule of law from the standpoint of employers. From the whole observed years 
there was no notion about skilled workers or how to attract them or even mentioning their benefits to the state economy.

Table 5: Mentions of migration and skilled migration at the Ministry of Industry and Trade website

\begin{tabular}{|c|c|c|c|c|}
\hline ঠँ & 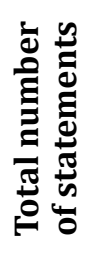 & 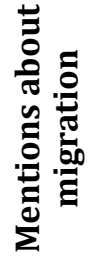 & 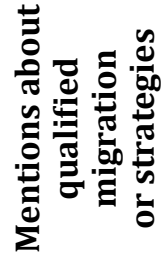 & 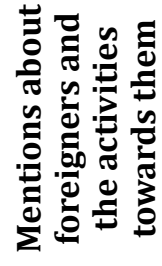 \\
\hline $\begin{array}{l}2019 \text { (up to } \\
\text { October 23) }\end{array}$ & 340 & 10 & 10 & 0 \\
\hline 2018 & 565 & 1 & 1 & 0 \\
\hline 2017 & 804 & 3 & 3 & 0 \\
\hline 2016 & 935 & 4 & 4 & 0 \\
\hline 2015 & 918 & 0 & 0 & 0 \\
\hline
\end{tabular}

Source: authors according to the webpage of MPO $(2019,2018,2017,2016,2015)$

Third, the Ministry of Industry and Trade as an actor who also participate in programmes on skilled migration was the one who mentioned this topic several times. However, still, we can say it is a minor topic for this ministry. The context concerned mostly employers and their interests in participating in those programmes. There were several calls to attract employers that would participate, most of the theme was to motivate employers. From our standpoint it seemed that those programmes concerning migration policy have more constraints so no major employer was more deeply interested.

We can introduce several explanations why migration policy regarding skilled migrants is not a popular topic even though it can be advantageous from many points of view - the economic or industrial among others. First, we have to say that there is not a huge gap because politicians themselves do not place a priority on this topic and are largely silent. One organization, which prioritizes the problem of the lack of skilled workers is the Confederation of Industry of the Czech Republic. It represents entrepreneurs and other organizations that deal with the problem and their aim is to put pressure on the ministries to solve the situation (SPČR 2019). While the programmes might work on the paper, the Ministry of the Interior does not see them as a priority in practice. Ministry of Labour and Social Affairs deals only with 
negative constraints that can arise from economic migration, but it does not participate in the positive effects. Ministry of Industry and Trade is one active actor, but towards employers, not the employees. One reason for such a lack of interest is that skilled migration is not a favourite topic among the voters. Skilled migration is still a topic of low politics. We can observe the realistic tendency to let this topic on the edge of the interest of the public. Sometimes this topic arises in something different. For example, the former Minister of Interior Chovanec used negative public attitudes towards migration to interpret this phenomenon (MVČR, 2018, more in Naxera, 2019). The policy regarding skilled migration is created but it might not be presented by the politicians because the public attitude in the Czech Republic is not open to migration in general (or when we speak about foreign workers in CR, not only skilled workers), with many people seeing migration as a challenge (Eurobarometer, 2019).

The implementation gap reveals whether migration policy on paper works by implementation through regulations and measures. We have shown the process of implementation itself in the section about the Kafkaesque reality of the programmes and now we would like to stress the main failures of migration policy regarding skilled workers. One problem of the Czech policy is the fragmentation when it comes to the actors involved in the process but also the lack of strategic vision which would enable to set this policy area as a priority. While the Czech state is generally unsupportive of migration, it can greatly benefit by opening up to skilled migration (see e. g. Grossmann - Stadelmann, 2013 for macro-level labour market effects).

The Strategy on the migration policy of the Czech Republic was approved in 2015. The document emphasizes mainly the word "legal", which is seen as beneficial for the state "to respond flexibly to the needs of its labour market and to reflect the long-term needs of the state" (MVČR, 2015, p. 2). Some deeper reflection about the sectors where skilled migration might be needed and how to attract foreign workers is missing. The problem is that the state is not planning what it can offer to foreign skilled workers and how to make their lives easier. Hence, it can lose the talents to other states which are better prepared to accommodate them. Since the sought-after fields such as healthcare and engineering do not vary across the hosting states, there is a lot of competition in attracting foreign workers.

Some issues make the process of accepting foreign workers slower and more arduous in the Czech Republic. One of them it the slow recognition of qualifications, so-called diploma recognition, or "nostrification" process, which happens in the Czech Republic (Leontiyeva - Pokorná, 2014). The 
novelization of the law that is in effect since September 2019 could help with this issue but so far, it is too early to evaluate its effects. The Strategic Framework 2030, a document that should ensure the competitiveness of the Czech Republic is aware of this tension. It states that

it will work on promoting (the Czech Republic) abroad and improving (its) reputation amongst foreigners who are highly skilled and qualified workers. (...) It will simplify the system of foreign education recognition so that the recognition procedure does not become an unnecessary obstacle (Government of the Czech Republic, 2017, p. 37).

It would seem that states according to this statement have an issue with promoting $\mathrm{CR}$ abroad and need to improve reputation. But it is not changing by those mentioned projects.

Another problem is that not only the administration but also the process of leaving the country itself may cost a lot and the individual needs to have a big financial reserve also due to the length of the process of acceptance in the Czech Republic. In this situation, the foreigner will choose the country which has the shortest processing periods and it is not likely to be the Czech Republic.

Last but not least, the number of available programmes and the involved actors complicate the whole process. This concerns the previous programme for qualified migrants from Ukraine and India (before September 2019) and the new programme extending it to migrants from Mongolia, Philippines, Serbia, Belarus, Montenegro, Kazakhstan and Moldova (after September 2019) and setting the quota for the respective employment categories. The new programmes are titled "Highly qualified employee", "Qualified employee" and "Key and scientific staff". However, it is not clear why quota for these respective nationalities was set under the Employee card if the Blue Card might be a sufficient tool to accept these workers. On top of that, the responsibilities for those programmes are fragmented. Ministry of Interior, Ministry of Labour and Social Affairs and Ministry of Industry and Trade duplicate roles (mainly overlapping its agenda). So unless there are any changes which would consolidate the programmes, increased fragmentation into more specific migrant categories will not bring any progress and the Czech Republic will stay behind other countries.

The efficacy gap should reveal, whether migration policy affects migration in real life, in other words, if it affects the direction of the flow, 
volume, composition, and timing. We would like to state that the migration policy regarding skilled workers influences the migrant flows to the Czech Republic. However, it is difficult to say whether it affects the flows positively or negatively. It is difficult to find aggregated macro data about skilled workers and their motives for coming to the Czech Republic that would show whether programmes work or not. The Czech Statistical Office only collects the numbers of migrants in different cities or regions and their gender but the skill levels are not accessible in its database. We can access some data, including the levels of education, about the job seekers from the Ministry of Labour and Social Affairs website but again, the picture is incomplete (MPSV, 2020). We see such a lack of database as one problem (gap) in the evaluation of policy by the government itself as they do not have feedback on the efficacy of the developed policy. We can conclude that this is one of the main problems connected with the topic of migration that politicians do not care so much about because they do not see costs from their efforts in such a policy. We have introduced such constraints that enabled the flow for many people for many reasons. One fact is that migration policy does affect the volume, due to administrative constraints. In table 6 below we add dependent variables, the summary of the current state of migration policy regarding skilled workers.

Table 6: Current state of migration policy regarding skilled workers

\begin{tabular}{|c|}
\hline Current state of migration policy in the Czech Republic \\
\hline process is not using benefits that could arise from skilled migration \\
\hline migration policy is caught in the more administrative framework \\
\hline qualitative move in the policy, but not the quantitative one in practice \\
\hline government does not see benefits that could be acquired from skilled migration \\
in a long-term period \\
\hline practice of policy is limited due to long processing \\
\hline programmes regarding skilled workers are not beneficial enough \\
\hline the programmes introduced in September 2019 still face the same constraints \\
the previous ones \\
\hline
\end{tabular}

Source: authors

Research of variables while reading laws, programmes, and ministries websites showed that ministries are concerned about independent variables. They took into account them while creating the migration policy. However, the intermediary variables such as interests of particular actors - 
ministries - are very important. It goes hand in hand with a specific person who is a head of ministry (an elected person, not an administrative worker) and this influences the activity towards skilled workers (make an attractive environment to come, stay, and have families).

From our standpoint the steps that could close gaps are clear. More attention to this topic is in ministries that have the aim to participate in skilled migration. Revise processes that would enable skilled workers to start faster with their work to eliminate huge costs on their side and make benefits for those workers different from the regular process. Keep the programme in mind while doing abroad activities.

\section{CONCLUSION}

So is the Czech Republic lagging behind other states when it comes to attracting the best and brightest? So far it is too early to judge if the changes implemented in September 2019 will bring more competitiveness to the Czech migration policy regarding skilled migration. However, the number of programmes currently in place and some administrative difficulties associated therewith show that the clarity for employers and employees is missing. We have shown that the numerous actors involved might be a weak spot of the Czech skilled migration policies. While viewing the situation in light of the migration policies across the EU, we did not include the major players in attracting skilled workers such as the USA, Canada or Australia because we argue that the Czech Republic will compete more with its neighbours such as Germany or Poland than with those countries. Yet it is possible to look at the best practices and see what makes those countries attractive - shorter waiting periods for the application, less paperwork, and good integration prospects, including the possibility to obtain permanent residence or citizenship of the country. However, all these knowledge CR ministries has, but they waste with it.

The following three policy gaps - the discourse, implementation, and efficacy gaps - regarding skilled migration policies in the Czech Republic were discussed in this paper. The first one reveals that skilled migration is not a priority in the discourse of the Czech policymakers across participated ministries. The explanation could be that while the policies exist on paper, the politicians prefer to tiptoe around them. Despite the clear benefits of skilled migration, there are very few state bodies that would openly advocate for improving skilled migration policies. This has to do with the second gap in the implementation of policies which shows that there are still certain 
barriers that prevent the policies from their successful realization. Some of the barriers are connected with the high fragmentation of the field and a large number of actors. The efficacy gap in the Czech skilled migration policies is hard to judge because of a lack of available data. However, it can be argued that some barriers which are currently in place in the Czech Republic make it harder for the skilled migration policies to be efficient.

When it comes to discussing skilled migration, we have also deliberately omitted one important category despite its salience - potential returnees (skilled Czechs currently working abroad) who might also be able to benefit the Czech economy. However, this group is currently lacking any structured support to do that and more research is needed on this group of return migrants. In the future, there will be no need for other employment categories in the Czech Republic; the current types of employment categories and documents are sufficient. There is no need to extend the programmes, create more quota for various nationalities but what is needed is to focus on what we already have and how to utilize the programmes to everyone's benefit and advantage. We need to set key priorities - not only who we want to attract but also how we are going to do that. And we will need to set the migrant workers as the priority - not the ministries, not the employers but the workers themselves. If we do not do it, they will go elsewhere where they will be able to utilize their full potential - without the administrative hurdles.

\section{REFERENCES}

ADAMS, R., PAGE, J. (2005). Do international migration and remittances reduce poverty in developing countries? In: World Development, Vol. 33, No. 10, 2005, pp. 1645-1669.

ADAMS, R. (2006). Remittances and poverty in Ghana. World Bank Policy Research Working Paper 3418, 2006.

BAMF (2018). Figures on the EU Blue Card. Berlin: BAMF - Federal Office for Migration and Refugees, [online]. Available at: <http://www.bamf. de/EN/Infothek/Statistiken/BlaueKarteEU/blaue-karte-eu-node.html>. [Accessed 10 September 2019].

BARŠOVÁ, A., BARŠA, P. (2005): Přistěhovalectví a liberální stát: imigrační a integrační politiky v USA, západní Evropě a Česku. Brno: Masarykova univerzita, 2005.

BAUEROVÁ, H. (2018). The Czech Republic and the Reality of Migrant Integration Policy in the Context of European Integration. In: Hrvatska $i$ 
komparativna javna uprava: časopis za teoriju i praksu javne uprave, Vol. 18, No. 3, 2018, pp. 397-420.

BHAGWATI, J. N. (1976). Taxing the brain drain. In: Challenge, Vol. 19, No. 3, 1976, pp. 34-38.

BRETTEL, B. C., HOLLIFIELD, F. J. (2015). Migration theory. Talking Across Disciplines. London: Routledge, 2015.

BROCHMANN, G., HAMMAR, T. (eds.) (1999). Mechanisms of Immigration Control. Oxford: Berg, 1999.

BURKERT, C., NIEBUHR, A., WAPLER, R. (2008). Regional disparities in employment of high-skilled foreigners: Determinants and options for migration policy in Germany. Leibniz - Information Centre for Economics

- Hamburg Institute of International Economics. Leibniz, 2008.

CORNELIUS, W. A., MARTIN, P. L., HOLLIFIELD, J. F. (1994). Controlling immigration: A global perspective. Stanford: Stanford University Press, 1994.

COUNCIL OF THE EUROPEAN UNION. (2009). Council Directive 2009/50/ EC of 25 May 2009 on the conditions of entry and residence of thirdcountry nationals for the purposes of highly qualified employment (OJ L 155, 18.6.2009, 17-29). Brussels: Council of the European Union, 2009. Available at: <https://eur-lex.europa.eu/legal-content/EN/ TXT/?uri=LEGISSUM\%3Al14573>. [Accessed 10 September 2019].

CZAIKA, M., DE HAAS, H. (2011). The effectiveness of immigration policies: $A$ conceptual review of empirical evidence. Oxford: International Migration Institute, 2011.

CZAIKA, M., DE HAAS, H. (2013). The Effectiveness of Immigration Policies. In: Population and Development Review, Vol. 39, No. 3, 2013, pp. 487-508. CZ-ISCO (2019). Klasifikace zaměstnání ISCO. [online]. Available at: <http:// www.cz-isco.cz/>. [Accessed 10 September 2019].

DOCQUIER, F. RAPOPORT, H. (2011). Globalisation, brain drain and development. IZA Discussion Paper No. 5590, 2011.

DRBOHLAV, D. (2010). Migrace a (i)migranti v Česku. Kdo jsme, odkud přicházíme, kam jdeme? Praha: SLON, 2010.

EUROPEAN COMMISSION. (2019). Eurobarometr - jaro 2019: Evropané nejoptimističtější za pět let, důvěra roste i v Česku, 5. 8. 2019. [online]. Available at: <https://ec.europa.eu/czech-republic/news/190805_ eurobarometr_cs>. [Accessed 23 April 2020].

FAIRCLOUGH, N. (1995). Critical discourse analysis. London: Longman, 1995. 
GIBSON, J., MCKENZIE, D. (2012). The economic consequences of brain drain of the best and brightest: Microeconomic evidence from five countries. In: Economic Journal. Vol. 122, No. 560, 2012, pp. 339-375.

GOVERNMENT OF THE CZECH REPUBLIC. (2017). Czech Republic 2030 - Strategic framework, 19. 4. 2017. [online]. Available at: <https:// ec.europa.eu/migrant-integration/librarydoc/czech-republic-2030--strategic-framework>. [Accessed 10 September 2019].

GOVERNMENT OF THE CZECH REPUBLIC. (2019). Results of the Government Meeting on August 26, 2019, 26. 8. 2019. [online]. Available at: <https:// www.vlada.cz/cz/media-centrum/tiskove-zpravy/vysledky-jednanivlady-26--srpna-2019-175678/>. [Accessed 10 September 2019].

GROSSMANN, V., STADELMANN, D. (2013). Wage effects of high-skilled migration: international evidence. In: The World Bank Economic Review. Vol. 27, No. 2, 2013, pp. 297-319.

HOLLIFIELD, J. F. (2000). Migration and the New International Order: The missing regime. In: Bimal, Ghosh. Managing Migration: The Need for a New International Regime. Oxford: Oxford University Press, 2000.

IHNED.CZ (2018). Firmy dusí nedostatek lidí, příští rok jich bude chybět půl milionu. Ekonomika kvůli tomu výrazně zpomalí, varuje Hospodářská komora. Ihned.cz, 15. 10. 2018. [online]. Available at: <https://byznys. ihned.cz/c1-66290980-v-cesku-chybi-440-tisic-zamestnancu-podnikyto-uz-ani-nehlasi-uradu-prace-podle-hospodarske-komory-lidiodcerpava-stat-a-nemecko>. [Accessed 10 September 2019].

IOM (2017). World Migration Report 2018. UN, New York, 2017. [online]. Available at: <https://doi.org/10.18356/f45862f3-en>. [Accessed 10 September 2019].

KING, R., OKÓLSKI, M. (2019). Diverse, Fragile and Fragmented: The New Map of European Migration. In: Central and Eastern European Migration Review. Vol. 8, No. 1, 2019, pp. 9-32.

KOSER, K., SALT, J. (1997). The geography of highly skilled international migration. In: International Journal of Population Geography. Vol. 3, No. 4, 1997, pp. 285-303.

KOSTELECKÁ, Y., BERNARD, J. KOSTELECKÝ, T. (2007). Zahraniční migrace vědců a výzkumníků a nástroje k jejímu ovlivnění. Sociologický ústav AV ČR, 2007.

KOUTNÁ, M., KRČKOVÁ, A., VAVŘINOVÁ, T. (2016). Educational Mismatch Among Immigrants in the Czech Republic-Selected Issues. In: Sociologia, Vol. 48, No. 6, 2016, pp. 572-600. 
KUBELKOVÁ, K. (2019). Prognóza vývoje počtu volných pracovních míst. Firmám chybí téměř půl milionu lidí. In: Businessinfo.cz. 5. 2. 2019. [online]. Available at: <https://www.businessinfo.cz/cs/clanky/ prognoza-vyvoje-poctu-volnych-pracovnich-mist-firmam-chybi-temerpul-milionu-lidi-118609.html>. [Accessed 10 September 2019].

KUSCHMINDER, K., STURGE, G., RAGAB, N. (2014). The contributions and barriers to knowledge transfer experienced by returning experts. CIM Working Paper Series No. 7, November 2014.

KUŠNIRÁKOVÁ, T., ČIŽINSKÝ, P. (2011). Dvacet let české migrační politiky: Liberální, restriktivní, anebo ještě jiná. In: Geografie, Vol. 116, No. 4, 2011, pp. 497-517.

KUVIK, A. (2012). Skilled migration in Europe and beyond: recent developments and theoretical considerations. In: Martinello, M., Rath, J. (eds.): An introduction to international migration studies. European perspectives. Amsterdam: Amsterdam University Press, 2012, pp. 211235.

LEONTIYEVA, Y. POKORNÁ, A. (2014). Faktory bránící využití kvalifikace imigrantů na trhu práce v ČR. Multikulturní centrum Praha, 2014.

LUCAS, R. EB (2005). International migration and economic development: Lessons from low-income countries. Northampton, MA: Edward Elgar Publishing, 2005.

MPO (2019a). Vláda schválila nové programy ekonomické migrace. Praha: MPO, 27. 8. 2019. [online]. Available at: <https://www.mpo.cz/cz/ rozcestnik/pro-media/tiskove-zpravy/vlada-schvalila-nove-programyekonomicke-migrace--248401/>. [Accessed 10 September 2019].

MPO (2019b). Čeští zaměstnavatelé budou snadněji zaměstnávat kvalifikované cizince. Praha: MPO, 3. 6. 2019. [online]. Available at: <https://www.mpo.cz/cz/zahranicni-obchod/ekonomicka-migrace/ cesti-zamestnavatele-budou-snadneji-zamestnavat-kvalifikovanecizince--246609/>. [Accessed 10 September 2019].

MPSV (2010). Projekt "Výběr kvalifikovaných zahraničních pracovníků" končí. Praha, MPSV, 13. 12. 2010. [online]. Available at: <https://www. mpsv.cz/files/clanky/9997/13122010.pdf>. [Accessed 10 September 2019].

MPSV (2018). Employee card - information for employers. Praha: MPSV, 20. 11. 2018. [online]. Available at: <https://portal.mpsv.cz/sz/zahr_zam/ zamka/zam\#povzm>. [Accessed 10 September 2019].

MPSV (2019). Oznámení cizince s modrou kartou o ukončení pracovního poměru, změně pracovního zařazení nebo změně zaměstnavatele. Praha: 
MPSV, 2019. [online]. Available at: <https://formulare.mpsv.cz/okprace/ cs/form/edit.jsp?FN=OznCizZm110201873\&CMD=EditForm\&SSID=k. EsMtAzcfDVjAiVVTFgECRJhQG.Qf0B >. [Accessed 10 September 2019]. MPSV (2020). Applicants from the EU / EEA registered in the Czech Republic - structure. [online]. Available at: <https://www.mpsv.cz/web/cz/ uchazeci-z-eu/ehp-evidovani-v-cr-struktura>. [Accessed 23 April 2020]. MVČR (2015). Strategy on Migration Policy of the Czech Republic. Praha, MVČR, 29. 7. 2015. [online]. Available at: <https://ec.europa.eu/migrantintegration/librarydoc/strategy-on-migration-policy-of-the-czechrepublic $>$. [Accessed 10 September 2019].

MVČR (2015). Tiskové zprávy. [online]. Available at: <https://www.mvcr. cz/clanek/tiskove-zpravy-2015.aspx>. [Accessed 10 September 2019]. MVČR (2016). Tiskové zprávy. [online]. Available at: <https://www.mvcr. cz/clanek/tiskove-zpravy-2016.aspx>. [Accessed 10 September 2019]. MVČR (2017). Tiskové zprávy. [online]. Available at: <https://www.mvcr. cz/clanek/tiskove-zpravy-2017.aspx>. [Accessed 10 September 2019]. MVČR (2018). Tiskové zprávy. [online]. Available at: <https://www.mvcr. cz/clanek/tiskove-zpravy-2018.aspx>. [Accessed 10 September 2019]. MVČR (2019). Tiskové zprávy. [online]. Available at: <https://www.mvcr. $\mathrm{cz} /$ clanek/informacni-servis-tiskove-zpravy-tiskove-zpravy.aspx>. [Accessed 10 September 2019].

NAXERA, V. (2019). Islamophobia without Muslims: Anti-Muslim and antiArab Attitudes in Czech Society (Introductory Remarks)," In: Gardocki, S., Ożarowski, R., Ulatowski, R. (eds.). The Islamic World in International Relations. Berlin: Peter Lang, 2019, pp. 251-267.

NOWICKA, M. (2012). Deskilling in migration in transnational perspective: The case of recent Polish migration to the UK. COMCAD Working Paper No. 112, 2012.

SAXENIAN, A. (2002). Silicon Valley's new immigrant high-growth entrepreneurs. In: Economic development quarterly. Vol. 16, No. 1, 2002, pp. 20-31.

SAXENIAN, A. (2006). The new Argonauts. Cambridge, MA: Harvard University Press, 2006.

SOLIMANO, A. (2008). The international mobility of talent and economic development: an overview of selected issues. In: Solimano, A. (ed.): The International Mobility of Talent: Types Causes and Development Impact. Oxford: Oxford University Press, 2008, pp. 21-43.

SPČR (2019). Evropský byznys $k$ nedostatku pracovníků s potrebnými dovednostmi. [online]. Available at: <https://www.spcr.cz/aktivity/ 
evropske-a-mezinarodni-vztahy/sp-v-mezinarodnich-organizacich/ businesseurope/13034-evropsky-byznys-k-nedostatku-pracovniku-spotrebnymi-dovednostmi>. [Accessed 10 September 2019].

STURGE, G., BILGILI, O., SIEGEL, M. (2016). Migrants' capacity as actors of development: do skills matter for economic and social remittances? In: Global Networks. Vol. 16, No. 4, 2016, pp. 470-489.

VALENTA, O., DRBOHLAV, D. (2018). Longitudinal and spatial perspectives on the mismatch of tertiary educated migrant workers in the Czech labour market: The case of Ukrainians. In: Moravian Geographical Reports. Vol. 26, No. 4, 2018, pp. 255-272.

VALENTA, O. (2013). Policy of attracting highly skilled professionals from the third countries to Czechia. In: Ergo. Vol. 8, No. 2, 2013, pp. 18-25. 